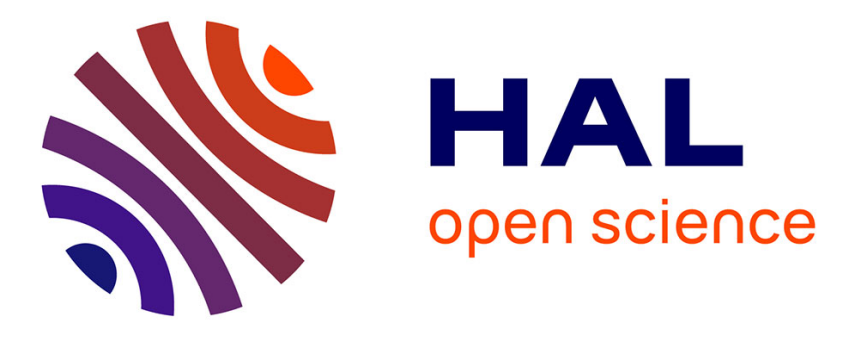

\title{
Microvesicles and Cancer Associated Thrombosis
}

Romaric Lacroix, Loris Vallier, Amandine Bonifay, Stephanie Simoncini, Diane Mege, Mathilde Aubert, Laurence Panicot-Dubois, Christophe Dubois, Francoise Dignat-George

\section{- To cite this version:}

Romaric Lacroix, Loris Vallier, Amandine Bonifay, Stephanie Simoncini, Diane Mege, et al.. Microvesicles and Cancer Associated Thrombosis. Seminars in Thrombosis and Hemostasis, 2019, 45 (06), pp.593-603. 10.1055/s-0039-1693476 . hal-02570599

\section{HAL Id: hal-02570599 https://hal-amu.archives-ouvertes.fr/hal-02570599}

Submitted on 15 May 2020

HAL is a multi-disciplinary open access archive for the deposit and dissemination of scientific research documents, whether they are published or not. The documents may come from teaching and research institutions in France or abroad, or from public or private research centers.
L'archive ouverte pluridisciplinaire HAL, est destinée au dépôt et à la diffusion de documents scientifiques de niveau recherche, publiés ou non, émanant des établissements d'enseignement et de recherche français ou étrangers, des laboratoires publics ou privés. 
2 Romaric Lacroix PharmD, $\mathrm{PhD}^{1,2}$, Loris Vallier PharmD ${ }^{1}$, Amandine Bonifay PharmD ${ }^{1}$, 3 Stephanie Simoncini $\mathrm{PhD}^{1}$, Diane Mege, $\mathrm{MD} \mathrm{PhD}^{1}$, Mathilde Aubert ${ }^{1}$, Laurence Panicot4 Dubois, $\mathrm{PhD}^{1}$, Christophe Dubois, Françoise Dignat-George PharmD, $\mathrm{PhD}^{1,2}$

5

6

1 Aix-Marseille University, INSERM, INRA, C2VN UMR_S1263, UFR de Pharmacie, 7 Marseille, France

$8{ }^{2}$ Department of Hematology and Vascular Biology, CHU La Conception, APHM, Marseille, 9 France

10

11

12

13

14

15

16

17

18

19

20

21

22

23

24 6

*Corresponding author : Francoise Dignat-George, C2VN, UMR_S1263, UFR de Pharmacie, Aix-Marseille Université, INSERM, Marseille, France

Tel : +3349135600

E-mail : Francoise.dignat-george@univ-amu.fr

7

Running Title: Microvesicles and cancer associated thrombosis 


\section{Abstract}

Microvesicles (MVs) are small membrane enclosed structures released into the extracellular space by virtually all cell types. Their composition varies according to the cell origin and the stimulus which caused their formation. They harbor functional molecules and participate in intercellular communication. Endothelium, inflammatory cells, and cancer cells produce procoagulant MVs which contribute to cancer-associated thrombosis (CAT) in animal models. The tissue factor (TF) conveyed by these MVs was shown to play a key role in different animal models of experimental CAT. Alternatively, other molecular mechanisms involving polyphosphates or phosphatidylethanolamine could also be involved. In clinical practice, an association between an increase in the number of TF-positive or the procoagulant activity of these MVs and the occurrence of CAT has indeed been demonstrated in pancreaticbiliary cancers, suggesting that they could behave as a biomarker predictive for CAT. However, to date, this association was not confirmed in other types of cancer. Potential causes explaining this limited associated between MVs and CAT are 1) the diversity of mechanisms associating MVs and different types of cancer; 2) a more complex role of MVs in hemostasis integrating their anticoagulant and fibrinolytic activity; 3) the lack of sensitivity, reproducibility and standardization of current methodologies permitting measurement of MVs. Each of these hypotheses constitutes an interesting exploration path for a future reassessment of the clinical interest of the MVs in CAT.

Key words: extracellular vesicles, microvesicles, cancer-associated thrombosis 


\section{Introduction}

Extracellular vesicles (EVs) constitute a heterogeneous population of small membrane enclosed structures released into the extracellular space by virtually all cell types. They can be divided in subpopulations based on specific characteristics like, biogenesis, size, content and biological function. EVs have been divided in 3 main categories according to their biogenesis. Exosomes are generated by fusion of the multivesicular bodies with the membrane. Ectosomes originate from the budding of cell membranes and are more often referred to as microparticles or microvesicles (MVs) whereas apoptotic bodies result from the late stages of apoptosis $(1,2)$. In this review, we will refer mainly to MVs, small membrane vesicles with a size between 100 and $1000 \mathrm{~nm}$ released from activated or apoptotic cells (3). Once released by the cells, MVs circulate in a variety of body fluids and vectorize information to multiple target cells in the body (3). MVs are extremely diverse depending on the inducer triggering their biogenesis and their parent cell. They are considered both as molecular signature of the cells from which they originate and as a depository of important biological information that can be exchanged with neighboring cells (4). Diversity of MVs origin is responsible for a diversity of structures and composition in lipids, proteins and nucleic acid such as mRNA and miRNA resulting in a diversity of functions. Because of the panel of selected molecules they bear, MVs have been involved in different pathophysiological processes such as coagulation, inflammation, angiogenesis or endothelial dysfunction $(5,6)$. This coagulo-inflammatory profile has logically led over the past decades to the question about their involvement in thrombosis. To address the question of the role of MVs in cancer associated thrombosis (CAT), MVs have to be integrated in their complex vascular environment with all partners contributing to thrombus formation including innate immune cells such as polymorphonuclear cells (PMNs) and monocytes, endothelial cells, platelets and also tumor cells. Additional partners resulting from cellular activation also include neutrophil extracellular traps (NETs) 
and Polyphosphates (PolyPs) (7). Moreover, MVs originating from normal and tumoral cells contribute to CAT, explaining that both common and cancer specific mechanisms are involved. After a rapid overview of MVs involvement in coagulation and CAT and their association with the development of clinical thrombosis, we will address the current causes potentially explaining why MVs were not always found associated to CAT including: 1) the diversity of CAT mechanisms, 2) the more complex role of MVs in hemostasis integrating their anticoagulant and fibrinolytic activity and 3) the lack of sensitivity, reproducibility and standardization of current methodologies allowing to measure MVs in clinical situations.

\section{MV involvement in coagulation and CAT}

MVs are procoagulant because they provide a catalytic surface for the assembly of different clotting factor complexes. Their procoagulant properties mainly rely on the exposure of anionic phospholipids, especially the phosphatidylserine (PS) on the external leaflet of the membrane after a calcium-dependent cellular activation (6). PS allows the binding of coagulation factors at the MVs surface by their carboxylglutamic acid-rich (GLA)-domains. A critical transporter with scramblase activity responsible for the PS exposure was identified as an anoctamin, the calcium-dependent channel TMEM16F (8). Accordingly, mutated form of TMEM16F lead to a defective PS membrane exposure and MVs shedding which is associated with a bleeding disorder in rare Scott Syndrome patients (9).

Besides PS, the presence of the coagulation initiator tissue factor (TF) on subsets of MVs also significantly contributes to their procoagulant activity. TF was initially identified on MVs after the observation that tumor cells release procoagulant vesicles $(10,11)$. PS and TF are not independent each other, indeed TF needs anionic phospholipids to be fully activated. It 
1 is the concentration of the same restricted surface of both molecules which lead to highly

2 procoagulant MVs. Incorporation of TF in PS+MVs is tightly regulated (12-16).

Once release in the circulation, TF positive MVs (TF+MVs) participate in a transfer of

information between cells at the crossroad between inflammation and thrombosis. Indeed, it was demonstrated that MVs released by activated endothelial cells induce TF-dependent pathways on monocytes (17) whereas activation of monocytes generate TF+MVs which induce a switch of the endothelium phenotype towards a proinflammatory profile. This profile is associated with the release of inflammatory cytokines, TF expression and release of new TF+MVs which can in turn transferred TF to platelets or activate monocytes and increase their TF expression (18). Consequently, TF expression on cells or MVs which initially do not express TF, is enabled by different mechanisms of membrane fusion (19) or endocytosis recycling (20).

The procoagulant potential of MVs depends on their cellular origin and the stimuli which triggered their formation. Platelet MVs (PMVs), the main source of MVs present the blood circulation $(21,22)$ are natively lacking TF-dependent procoagulant activity (23). When observed, the TF activity on PMVs may result from the fusion of endothelial or monocytederived TF+MVs with activated platelets as described above. Moreover, the PS-rich environment generated by PMVs may amplify the TF+MVs activity from MVs from another source. It was also showed that PMVs represent an appropriate surface to activate the contact phase pathway (24). Similarly, erythrocyte-derived MVs (EryMVs) trigger the coagulation independently of TF but in a contact phase-dependent manner (25).

Among leucocytes, monocyte-derived MVs (MoMVs) represent a major component of the TF+MVs circulating pool (26). As recently reviewed by Halim et al (27), TF on MoMVs can be upregulated by several factors including LPS (lipopolysaccharide) and proinflammatory cytokines such as $\mathrm{TNF} \alpha$ and Interleukin (IL)-1 $1 \beta$. Interestingly, it was 
recently shown that the different human monocyte subsets generated MVs with different procoagulant potential after stimulation by IL-33 (28). In contrast to MoMVs, granulocytederived MVs (Gran-MVs) generated only a low level of TF activity, if any, while this property may be observed in pathological situations (29), although MoMVs transfer to granulocytes cannot be excluded (30).

Endothelial-derived MVs (EMVs) harbor PS and TF-dependent procoagulant activity in response to a variety of stimuli including cytokines, complement, and LPS and therefore contribute to the circulating pool of $\mathrm{TF}+\mathrm{MVs}$ in clinical situation where the endothelium is activated (5). Cancer MVs represent another set of procoagulant MVs. Cultured human tumor cell lines of different origins express variable levels of TF and release cancer MVs with various procoagulant potentials in their supernatant $(31,32)$. As illustrated for breast cancer, according to the cell line, mechanisms involve TF-independent pathways which promote platelet activation and aggregation and/or TF-dependent thrombin generation (33).

Evidence of MVs involvement in thrombus formation in vivo is supported by different studies using endogeneously formed or exogeneously injected MVs and mice mouse models of thrombosis. The pioneering work by Furies's group in 2003 showed that MoMVs rapidly accumulate at the site of injury in a laser injury model of small cremaster muscle arteries $(34,35)$. This result was reproduced in various murine model of arterial and venous thrombosis with different sources of MVs (36-40).

\section{MVs association with the development of clinical thrombosis}

Cancer patients have an increased risk of thrombosis, especially venous thromboembolism (VTE), which differs according to the type of cancer $(31,41)$. Although cancer is known as a hypercoagulable state, the pathogenesis is not totally elucidated. TF bearing MVs has been 
assessed as a risk factor for cancer related VTE in several studies. The 5 main retrospective studies $(31,42-45)$ that analyzed the link between TF+MVs and VTE demonstrated increased levels of circulating TF+MVs(measured by flow cytometry and functional assays) in cancer patients with VTE compared with cancer patient without VTE, with the highest values found in patients with pancreatic cancer.

The main prospective studies are listed in table 1 . The first one supporting the hypothesis that high levels of TF+MVs activity predicts VTE in pancreatic cancer was performed by Khorana et al (46). Since this initial work, several other prospective studies, measured TF-MVs to evaluate the relationship between $\mathrm{TF}+\mathrm{MVs}$ and future development of VTE. A positive association was found in studies using reported methodologies $(43,47-49)$ including the most recent studies (50-52) whereas it was not found in other large studies (53-55). A recent metaanalysis on the relationship between TF+MVs and cancer patients with VTE concluded that the increased presence of TF+MVs represents an increased risk for cancer patients VTE with an overall odds ratio (OR) of 1.76 (56). However, due to the heterogeneity of study design, methods to measure TF-MVs, cancer origins and causes of death, more well-designed studies and more comprehensive adjustments for confounders are needed to confirm this association. Indeed, it is most likely that the results of the aforementioned studies are primarily driven by pancreaticobiliary cancer.

From these clinical studies, it seems that MVs have a real potential to predict CAT. However, most of these studies have limitations including a low number of patients, and the fact that few of them rely on multicenter prospective designs. More importantly these studies display a broad methodological heterogeneity and lack of standardization. We will now address the potential causes explaining that MVs are not always associated to CAT including: 1) the diversity of CAT mechanisms, 2) the more complex role of MVs in hemostasis 
1 integrating their anticoagulant and fibrinolytic activity and 3) the lack of sensitivity, reproducibility and standardization of current methodologies allowing to measure MVs in clinical situations.

\section{MVs and the diversity of cancer associated thrombosis mechanisms}

Over the past years, a special attention has been given to CAT and the underlying mechanisms linking MVs and the thrombus formation (Figure 1). Several mouse models of cancer-associated thrombosis have been used with different mouse strains, tumors, tumor sites and thrombosis models (40). As a result, it seems that the importance of MVs and the mechanisms involved may vary according to the cancer origin (57). Consequently, the relevance of measuring MVs as a biomarker of CAT may similarly vary according to the cancer origin. Moreover, the exact nature of what should be measured on these MVs may also not be restricted to TF.

Pancreatic cancer was the most studied, due to its high rate of CAT (58). The role of pancreatic cancer-derived MVs in thrombosis has been first studied with the model of Panc02 pancreatic tumor cell lines. Using the ferric chloride mesentery vessel model and an ectopic pancreatic cancer mice model, a first study demonstrated that MVs released by $\mathrm{PancO} 2$ cell are detectable in mice peripheral circulation and accumulated in developing thrombus. Thrombus formation was reduced by inhibition of P selectin suggesting a P-selectin / PSGL-1 interaction may be invoved (59). In this model, thrombus growth induced by both exogeneously infused tumor-MVs and endogenous MVs, was prevented by inhibition of platelet activation by clopidrogrel and by blocking $\alpha v \beta 1 / \beta 3$ integrins, suggesting that tumorMVs bind to the thrombus on activated platelets in an integrin-dependent manner (60). Injection of the PancO2 derived MVs in the inferior vena cava (IVC) stenosis models 
significantly increased the number of mice developing a thrombus but also the thrombus size (61). Interestingly, when MVs with low TF were injected, significantly less mice developed a thrombus, showing that $\mathrm{TF}$ from tumoral $\mathrm{MVs}$ is essential to their thrombus promoting activity. It was also recently shown that infusion of tumor-MVs resulted in the activation of platelets both in vitro and in vivo as suggested by the accumulation of platelets in the lung (62). Thus TF+MVs enhance VTE both by increasing fibrin formation but also by activating platelets. The direct demonstration of the role of TF on MVs originating from the tumor cell itself has recently been confirmed in a recent study performed with human pancreatic BxPc-3 grown orthotopically in nude mice (Figure 1A). In the IVC stenosis model, inhibition of human TF reduced the clot size in tumor-bearing mice but did not affect clot size in control mice. These results demonstrate that $\mathrm{TF}+\mathrm{MVs}$ released from pancreatic tumors are responsible for increased clot size in tumor bearing mice (63). Interestingly, inflammation is a further putative pathway that could provide the trigger driving the procoagulant response with a particular relevance for the development of VTE in pancreatic cancer. In this model, high levels of TF+MVs are present and increased leukocyte infiltration contributes to promotes TF pathway and proinflammatory effects. Anticoagulant mechanisms are overwhelmed by the high levels of TF which accumulate in endothelial cells (ECs) and TF is recycled to the EV surfaces with PS, resulting in apoptosis, junctional weakening and subsequent endothelial denudation, resulting in activation of the extrinsic pathway via Xa activation $\mathrm{TF}+\mathrm{MVs}$ in the context of acute inflammation (64). Beside TF pathway, another alternative novel pathway was also recently reported, using an IVC flow restricted model and strains of genetically engineered mice lacking GP1b or expressing reduced levels of TF (65). The mechanisms are independent of platelets and myeloid cells and involves the synergistic activation of coagulation by pancreatic MVs and host TF. A major contribution of the procoagulant activity of pancreatic MVs was provided by phosphatidylethanolamine (PE) externalization which 
supported robust generation of Xa (Figure 1C). Disrupting PE dependent activation of factor X suppressed pancreatic MVs induced DVT without causing changes in hemostasis (65). In terms of therapy, this study confirms the observation that low molecular weight heparins are effective for prevention and treatment of CAT $(66,67)$ but also suggests that oral actor Xa inhibitors may also be even more effective and tolerated (68).

In other cancers, TF is not necessary the major pathway by which MVs can promote VTE. For example, in prostate cancer, a recent work using mice knock-out for FXII, FXI and kininogen showed that these mice were protected against pulmonary embolism by the infusion of prostate cancer-derived MVs (69). These tumor-MVs also exhibit polyphosphates which suggests that tumor generated polyphosphate-rich MVs may activate the contact pathway (Figure 1B), favoring the thrombus formation (70). In brain cancers, platelet aggregation is a mechanism by which brain tumors may release podoplanin (PDPN) positive MVs in the circulation, that could activate circulating platelets (Figure 1D), resulting in increased VTE in patients with brain cancer (71-73). Additionally, mammary carcinoma derived EVs induce the formation of NETs which may represent another mechanism linking MVs and thrombosis (74). Thus according to the type of cancer, TF-independent mechanisms associated with MVs can also be involved in CAT and thus represent a potential cause explaining why an association between the biomarker TF+MVs and CAT was not always found.

\section{A more complex role of MVs in hemostasis}

Beside their well-documented procoagulant activity, MVs vectorize anticoagulant and fibrinolytic molecules which may balance the resulting effect of MVs in the hemostasis equilibrium (Figure 2). 

cells which may be activated in the tumoral environment such as platelets, leukocytes and endothelial cells. Anticoagulant proteins S and C, as others vitamin K-dependent molecules,

can bind to the MVs surface on anionic PS residues and directly inhibit the procoagulant activity of platelet MVs (75-77). The endothelial protein C receptor (EPCR) (78) and thrombomodulin (79) have been reported not only on endothelial-derived MVs generated in vitro but also among circulating MVs in patients $(80,81)$. Regulatory molecules such as TFPI (TF pathway inhibitor) was detected on leukocytes and endothelial MVs (82). Thus, the thrombogenicity of MVs depends on a balance between the pro- and anti-coagulant molecules which may vary among various disease conditions. For instance, the TF/TFPI balance of MVs has been evaluated in 26 patients with cancer from various origins compared to 92 healthy control volunteers. As a result, the ratio of TF/TFPI MVs was significantly increased in the cancer patients due to a significant decrease of the percentage of TFPI+ MVs (83). The same team also recently showed that this balance is modified by chemotherapy drugs. Indeed, a significant increase in the circulating MVs TF/TFPI ratio was found after the first 24 hours of doxorubicin treatment (84). Consistently, tumoral MVs derived from MDA-MB-231 cells stimulated with high-dose doxorubicin display a strong decrease in the TFPI levels resulting in a six-fold increase in their procoagulant activity (82). Interestingly, in these studies, the critical variable was the level of the anticoagulant molecule on the MVs surface. These results stress/emphasize the importance of taking into account both the procoagulant and the anticoagulant molecules on the MVs surface to better reflect their global effect. In practice, the presence of these anticoagulant molecules such as TPFI may impact in the resulting MVs procoagulant activity measured by functional assays. Indeed, the inhibition of TFPI increases their sensitivity to procoagulant MVs $(85,86)$. However, how the balance of TF/TFPI on 
1 circulating MVs is modified by the pre-analytical and analytical protocols remains to be clarified.

The role of MVs in hemostasis is further complicated by the presence of fibrinolytic activity. Initially, proteolytic molecules such as metalloproteinases and the urokinase(uPA)/uPA receptor have been reported on MVs from tumoral cell lines in vitro (87-89) and from ascites from patients with ovarian cancers (90-92). Tissue-type plasminogen activator (t-PA) was also identified on MVs derived from a prostate cancer cell line (93). This tumoral MV proteolytic activity was first associated with an increased cellular invasiveness and metastasis (94-96). It was shown that hsp90alpha is secreted in small EV and interacts with tPA and its receptor annexin II in invasive cancer cells and contributes to their invasive nature by enhancing the conversion of plasminogen to active plasmin (97). Finally, the complete panel of molecules allowing MVs to efficiently generate plasmin and to vectorize a fibrinolytic activity was found to be present at their surface. This was first demonstrated on MVs from endothelial origin in vitro $(98,99)$ and extended to leucocyte MVs (100). The plasmin generation capacity involves the binding of plasminogen on a specific receptor such as alpha-enolase and its activators such as uPA or tPA on receptors specific to surface of the MVs (101). Interestingly, this MV-dependent activity was found on circulating MVs of patients including cancer patients with acute promyelocytic leukemia $(100,102)$. The fibrinolytic potential varies according to the cellular origin and the vesicular subsets. Comparison of the thrombotic and fibrinolytic activity of exosomes and MVs from several tumor cell lines showed that exosomes and/or MVs from most cell lines (MCF7, NB4, MDAMB-231) with the exception of the A549 cell line, displayed fibrinolytic activity toward a pure fibrin clot, while only exosomes from MDA-MB-231 cells could degrade a fibrin clot formed in plasma (103). Interestingly, this fibrinolytic potential could be transferred from cell 
1

to cell by exosomes. Indeed, the incubation of MDA-MB-231 cell-derived exosomes with A549 cells increased plasmin generation by these cells (103).

Plasmin generation is a highly regulated process controlled by a balance between activators and inhibitors. The plasminogen activator inhibitor (PAI-1) has been detected on tumoral MVs surface. MVs derived from leukemic mast cells inhibit the process of fibrinolysis by increasing the expression and secretion of PAI-1 (104). It has been also recently shown that the active oncogene EGFRvIII increased the concentration of TF and PAI-1 in prostate cancer derived MVs increasing their procoagulant activity (105).

Presence of both procoagulant and profibrinolytic activity at the surface of MVs lead us to propose that the resulting effect on bleeding or thrombotic events will be oriented as a function of the balance between the MV-dependent procoagulant and fibrinolytic activities $(106,107)$. This concept of the coagulo-fibrinolytic balance of MVs was recently evaluated in the context of the fibrinolytic imbalance associated with septic shock. In a preliminary study, we showed, that the MVs fibrinolytic activity was significantly higher in septic shock patients who survived compared to those who died and that this MV-dependent activity was inversely correlated with multiorgan failure scores and ischemic markers (108). However, to what extent the fibrinolytic side may counterbalance the procoagulant side and play a significant role in the cancer-associated thrombosis pathophysiology is still largely unknown. Similarly, whether the coagulo-fibrinolytic balance of MVs is a better predictor of the occurrence of thrombosis in cancer patients rather their procoagulant activity alone, remains to be evaluated with suitable methodologies.

\section{Methodological considerations}


The reported limited performance of MVs as biomarker to accurately predict the risk of thrombosis in cancer patients, may also originate from methodological issues.

Pre-analytics remains an important source of artifacts. Recommendations have been

made but they are not always easy to apply in clinical studies $(109,110)$. Moreover, several functional assays require MV isolation from the body fluids before performing the test. For many years, ultracentrifugation has been used. However, the centrifugation step significantly decreases the reproducibility of the assays and may impede inter-laboratory comparisons. Immunocapture on magnetic beads may represent a useful alternative (108).

The two main approaches which have been applied to evaluate the potential of MVs biomarker of cancer associated thrombosis are: 1) the antigenic detection of procoagulant molecules at the surface of MVs (111), or 2) the functional capacity of MVs to generate factor Xa, thrombin or a clot. Combined strategies have also been developed (112) (Table 2).

Among antigenic assays, flow cytometry (FCM) was used for the detection of procoagulant molecules such as PS with annexin $\mathrm{V}$ or lactadherin and TF with specific antibodies. Over the past few years, significant improvements have been made regarding the sensitivity of FCM to detect single vesicles with a diameter of $<300 \mathrm{~nm}$ which have further established this methodology as the most promising tool for routine enumeration of EV subsets $(113,114)$. However, the lack of sensitivity of the current flow cytometers to characterize small MVs and to detect small amount of molecules at the MVs surface still impede this evaluation. Moreover, most FCM studies did not take into account the presence of other active PLs, such as PE or the presence of physiological inhibitors regulating the procoagulant activity such as TFPI. As an interesting alternative, we measured fibrin+ (positive) MVs by FCM in pancreatic and colorectal cancers. The hypothesis was that as fibrin is the final product of the coagulation cascade, the level of fibrin+MVs may directly reflect the activation state of the blood coagulation cascade. As a result, fibrin+MVs were 
1 significantly increased in patients with thrombosis (39). Other antigenic methods have been recently proposed such as the detection of TF+MVs by scanning confocal microscopy (115).

3 Regarding functional tests, a first group of methods focuses on the PS-dependent 4 procoagulant activity of MV:

1. PS contribution can be evaluated measuring a PL-dependent coagulation time after dilution in a PL-depleted plasma and activation with factor Xa (FXa) and calcium. Thus, the only PLs present in the reaction mixture are provided by the patient sample. This test, initially described by Exner et al. (116), is commercially available (XaCT test, Haematex, Australia; STA-Procoag-PPL, Stago, Paris, France) and can be fully automated on routine hemostasis instruments.

2. Other assays combine solid-phase capture of MVs on annexin V and thrombin generation (Zymuphen-MP ELISA kit, Hyphen Biomed, Neuville-sur-Oise, France) (117). The generation of thrombin after adding prothrombin, FXa, FVa and calcium, is measured via cleavage of a chromogenic thrombin substrate producing absorbance at $405 \mathrm{~nm}$. A standard curve of known MVs concentration is used to convert the absorbance into nM PS. This test may be adapted to quantify different subsets of MVs substituting annexin V by various capture antibodies. However, the sensitivity of these methods is limited by a heterogeneous and passive sedimentation of MVs and a limited contact surface.

3. The Calibrated Automated Thrombogram assay was originally developed by Hemker et al. for measuring thrombin generation in platelet-rich or platelet-poor plasma in a variety of clinical settings (Calibrated Automated Thrombogram, Thrombinoscope BV, Maastricht, NL and Stago) (118). To evaluate the PS contribution of MVs, thrombin generation is initiated by the addition of a reagent containing tissue factor and a minimal amount of PLs (platelet poor plasma reagent). Thrombin generation is 
monitored with a thrombin fluorogenic substrate. The use of a thrombin calibrator for each individual plasma corrects for donor-to-donor differences in color of plasma, inner filter effects and substrate consumption. This assay is sensitive to the contact phase activation. Alternatively, plasmatic MVs can be pelleted, washed and resuspended in MV-free plasma. The reproducibility of the measurement will decrease, but the measurement of thrombin generation will not be affected by soluble factors, the presence of anticoagulants or a coagulopathy.

A second group of assays focuses on the measurement of TF-dependent procoagulant activity of MVs :

1. The calibrated automated thrombogram assay can be modified to be more sensitive to TF. Thrombin generation in platelet free plasma or purified MVs spiked in MV-free plasma is initiate in presence of a "MP reagent" which contents only PLs and no TF. This assay is sensitive to the contact phase activation. Even if this test is more sensitive than the Zymuphen-TF (described below) in a Neisseria meningitidisstimulated whole blood model (119), high concentrations of TF+MVs are necessary to be detectable probably because of a masking effect due to the high concentration of PLs added in the test.

2. Most of the studies evaluating the potential interest of MVs as a biomarker of the cancer-associated thrombosis have measured procoagulant MVs with FXa generation assays as a read-out of TF-FVIIa activity (120). These assays have been performed using either antibody-mediated MVs captured on coated plate or isolation of the MVs by high-speed centrifugation. In the commercially available assay (Zymuphen-TF, Hyphen Biomed), MVs are captured using an anti-TF antibody which does not interfere with TF activity. Unfortunately, no anti-TF inhibitor antibody is incorporated during the measurement of FXa. It was found that this assay has reduced specificity 
and sensitivity compared with an "in-house" assay that isolates MVs using centrifugation (121). Two slightly different "in house" assays have been reported for the measurement of TF-MVs activity after isolation of MVs by high speed centrifugation. MVs are washed then resuspended in buffer before measuring FXa. Both assays use commercially available Dade thromboplastin reagent Innovin as a standard. FVII is added with synthetic PLs in the "kinetic assays" (42) whereas FVIIa is used without adding PLs in the endpoint assay (46). A moderate correlation was found ( $\mathrm{r}=0.61, \mathrm{P}<0.001)$ between the two assays in 54 pancreatic cancer patients $(54)$. Several ongoing developments are improving the sensitivity of these assays $(122,123)$. Alternatively, a more global assay has been proposed monitoring the fibrin generation (FGT; fibrin generation test) after incubating purified MVs by high speed centrifugation in a plasma in presence of anti-TF or anti-FXII blocking antibodies $(124,125)$. Clotting is initiated by addition of calcium and fibrin formation is monitored by kinetic measurement of the optical density at $405 \mathrm{~nm}$.

Data comparing all these methods to measure the procoagulant potential of MVs are lacking. Moreover, FCM is the only method which benefits from a standardization effort so far which lead to different tools to reduce the inter-laboratory variability $(123,124)$. This work is currently ongoing in a collaborative workshop on the standardization of EVs combining the experts from three international societies: International Society on Extracellular Vesicles (ISEV), International Society on Advancement of Cytometry (ISAC), and the International Society on Thrombosis and Haemostasis (ISTH). However, development of international standards is still needed to compare the results in the field. In a timely manner a new ISTH workshop, comparing the sensitivity and the specificity of assays to measure TF-MV in plasma samples will start this year. Results of these studies will certainly provide important 
1 information to progress toward the optimal methods to measure MVs and standardization

2 tools mandatory for robust multicenter studies in the cancer associated thrombosis field.

\section{Conclusions}

6 Up to now, several issues explain why MVs are not systemically found associated with CAT,

7 including the diversity of mechanisms associating MVs and different types of cancer, the complex role of MVs in hemostasis integrating their anticoagulant and fibrinolytic activity and the limited sensitivity, reproducibility and standardization of current methodologies allowing to measure MVs. Continuation of the technical development for measuring MVs, standardization of methods in combination with efforts to define the most interesting antigenic or functional target to be measured on MVs in different clinical settings are issues that need to be addressed during the coming years. In addition, modulating MVs with treatment, and the benefits of regulating MVs in the prevention of future cardiovascular events are to be tested in prospective large randomized trials. Altogether, the rapidly growing knowledge on the biology of EV combined with the many technological advances set high expectations for future clinical applications of MVs as a predictive biomarker for CAT. 


\begin{tabular}{|c|c|c|c|c|c|}
\hline Patients & Wo VTE / W VTE & Follow-up & $\begin{array}{c}\text { MV } \\
\text { phenotype }\end{array}$ & Method & Reference \\
\hline $\begin{array}{l}\text { Locally advanced or } \\
\text { metastatic pancreatic } \\
\text { cancer }\end{array}$ & $11 / 02$ & $\begin{array}{c}\text { Every } 4 \\
\text { weeks for } \\
20 \text { weeks }\end{array}$ & $\mathrm{TF}+\mathrm{MV}$ & Functional assay & $\begin{array}{c}\text { Khorana, JTH, } 2008 \\
\text { (46) }\end{array}$ \\
\hline Cancer Wo VTE & $60 / 5$ & 1 year & $\mathrm{TF}+\mathrm{MV}$ & Impedance FMC & $\begin{array}{c}\text { Zwicker, Clin. Cancer } \\
\text { Res., } 2009 \text { (43) }\end{array}$ \\
\hline $\begin{array}{c}\text { Solid and } \\
\text { hematological cancer }\end{array}$ & $728 / 53$ & 2 years & $\mathrm{PS}+\mathrm{MV}$ & Functional assay & $\begin{array}{c}\text { Thaler, Ann. Hematol., } \\
2011 \text { (53) }\end{array}$ \\
\hline Cancer Wo VTE & $\begin{array}{l}299 \text { (48 pancreatic) / } \\
49 \text { (12 pancreatic) }\end{array}$ & 2 years & $\mathrm{TF}+\mathrm{MV}$ & $\begin{array}{l}\text { Functional assay } \\
\text { (chromogenic end } \\
\text { point and kinetic) }\end{array}$ & Thaler, JTH, 2012 (54) \\
\hline $\begin{array}{c}\text { Cancer Wo VTE at } \\
\text { study entry }\end{array}$ & $43 / 5$ & 6 months & $\begin{array}{c}\text { Annexin V + } \\
\text { MV }\end{array}$ & FCM & $\begin{array}{c}\text { Van Doormaal, Thromb. } \\
\text { Haemost., } 2012 \text { (47) }\end{array}$ \\
\hline Pancreatic Cancer & $252 / 40$ & 10 months & $\mathrm{TF}+\mathrm{MV}$ & FCM & $\begin{array}{c}\text { Hernandez, Thromb. } \\
\text { Haemostat., } 2013 \text { (55) }\end{array}$ \\
\hline $\begin{array}{c}\text { Cancer Wo VTE at } \\
\text { study entry }\end{array}$ & $43 / 5$ & 6 months & $\mathrm{TF}+\mathrm{MV}$ & Functional assay & $\begin{array}{c}\text { Van Doormaal, Thromb. } \\
\text { Haemost., } 2012 \text { (47) }\end{array}$ \\
\hline $\begin{array}{l}\text { Glioblastoma } \\
\text { multiforme }\end{array}$ & $61 / 11$ & 7 months & $\mathrm{TF}+\mathrm{MV}$ & FCM & $\begin{array}{c}\text { Sartori, Thromb. } \\
\text { Haemost., } 2013 \text { (48) }\end{array}$ \\
\hline $\begin{array}{c}\text { Pancreatobilary } \\
\text { cancer }\end{array}$ & $117 / 52$ & $\begin{array}{c}\text { Not } \\
\text { specified }\end{array}$ & $\mathrm{TF}+\mathrm{MV}$ & Functional assay & $\begin{array}{l}\text { Bharthuar, Thromb. } \\
\text { Res., } 2013 \text { (49) }\end{array}$ \\
\hline Pancreatic cancer & $65 / 11$ & $\begin{array}{c}6 \text { months - } \\
1 \text { year }\end{array}$ & $\mathrm{TF}+\mathrm{MV}$ & Functional assay & $\begin{array}{c}\text { Woei-A-Jin, B J Cancer, } \\
2016(50) \\
\end{array}$ \\
\hline Cancer Wo VTE & $\begin{array}{l}608 \text { (90 pancreatic) / } \\
40 \text { (10 pancreatic) }\end{array}$ & 180 days & $\mathrm{TF}+\mathrm{MV}$ & $\begin{array}{l}\text { Functional assay } \\
\text { (Fibrin generation } \\
\text { and FXa } \\
\text { generation }\end{array}$ & $\begin{array}{c}\text { Van Es, Thromb. Res., } \\
2018 \text { (51) }\end{array}$ \\
\hline Pancreatic cancer & $41 / 12$ & 1 year & $\mathrm{TF}+\mathrm{MV}$ & Functional assay & $\begin{array}{l}\text { Faille, Oncotarget, } 2018 \\
(52)\end{array}$ \\
\hline
\end{tabular}

9 Table 1 : Role of MVs as prognostic biomarkers of VTE in cancer patients. FCM: Flow- 
1 factor; VTE: Venous thromboembolism; Wo/W: Without/With. White lines represent studies

2 no associations found between cancer and VTE and grey lines represent studies with a

3 significant association between cancer and VTE.

4

5

6

7

\begin{tabular}{|c|c|c|c|c|c|c|}
\hline Assays & Strategy & Target & Method & Preanalytics & $\begin{array}{c}\text { EV } \\
\text { commercial } \\
\text { kit }\end{array}$ & Reference \\
\hline Flow cytometry & Antigenic & $\begin{array}{l}\text { PS, TF, } \\
\text { TF/TFPI }\end{array}$ & Immunofluorimetry & PFP & No & $\begin{array}{l}\text { Poncelet et al Trasci } \\
2015 \text { (113), Nolan et al } \\
\text { Platelets } 2017 \text { (114) }\end{array}$ \\
\hline Flow cytometry & Antigenic & Fibrin & Immunofluorimetry & PFP & No & $\begin{array}{c}\text { Mege et al Oncotarget } \\
2017(39)\end{array}$ \\
\hline $\begin{array}{l}\text { Scanning } \\
\text { confocal } \\
\text { microscopy }\end{array}$ & Antigenic & $\mathrm{TF}$ & Immunofluorimetry & $\begin{array}{c}\text { PFP / } \\
\text { Centrifugation }\end{array}$ & No & $\begin{array}{c}\text { Hisada et al Thromb Res } \\
2017(115)\end{array}$ \\
\hline $\begin{array}{c}\text { Calibrated } \\
\text { Automated } \\
\text { Thrombogram }\end{array}$ & Functional & $\begin{array}{l}\text { PS or } \\
\text { TF }\end{array}$ & $\begin{array}{l}\text { Thrombin } \\
\text { generation }\end{array}$ & PFP & Yes & $\begin{array}{c}\text { Hemker et al, } \\
\text { Pathophysiol. Haemost. } \\
\text { Thromb. } 2002 \text { (118) }\end{array}$ \\
\hline $\begin{array}{l}\text { STA-Procoag } \\
\text { PPL }\end{array}$ & Functional & PS & Coagulation time & PFP & Yes & $\begin{array}{c}\text { Exner et al, Blodd } \\
\text { Coagul. Fribinolysis, } \\
2003(116)\end{array}$ \\
\hline $\begin{array}{l}\text { Zymuphen-MP } \\
\text { ELISA Kit }\end{array}$ & Combined & PS & $\begin{array}{l}\text { Thrombin } \\
\text { generation }\end{array}$ & $\begin{array}{l}\text { Immunocapture } \\
\text { (PS) on PFP }\end{array}$ & Yes & $\begin{array}{l}\text { Laroche et al Platelets } \\
2017(112)\end{array}$ \\
\hline $\begin{array}{c}\text { Zymuphen-MP } \\
\text { TF }\end{array}$ & Combined & $\mathrm{TF}$ & FXa generation & $\begin{array}{l}\text { Immunocapture } \\
\text { (PS) on PFP }\end{array}$ & Yes & $\begin{array}{l}\text { Laroche et al Platelets } \\
2017(112)\end{array}$ \\
\hline $\begin{array}{c}\text { Factor Xa } \\
\text { generation assays }\end{array}$ & Functional & $\mathrm{TF}$ & FXa generation & Centrifugation & No & $\begin{array}{c}\text { Khorana et al, JTH, } 2008 \\
\text { (46), Woei-A-Jin, B J } \\
\text { Cancer, } 2016 \text { (50) }\end{array}$ \\
\hline $\begin{array}{l}\text { Fibrin generation } \\
\text { assay }\end{array}$ & Functional & $\mathrm{PS}+\mathrm{TF}$ & Fibrin generation & Centrifugation & No & $\begin{array}{c}\text { Berckmans et al, Blood, } \\
\text { 2011(125) }\end{array}$ \\
\hline
\end{tabular}

8

9 Table 2: Procoagulant assay. Different strategies were used: antigenic assay using flow

10 cytometry, functional assay using coagulation time, factor $\mathrm{Xa}$ (FXa) generation assay,

11 thrombin generation assay or fibrin generation assay. PFP: Platelet Free Plasma; PS:

12 Phosphatidylserin; TF: Tissue factor; TFPI: TF pathway inhibitor. 
2 Figure 1: Diversity of mechanisms involving MVs in cancer associated thrombosis.

3 MoMVs and MVs originating from the tumor cell itself rapidly accumulate at the site injury,

4 increase fibrin formation and activating platelets(A). Tumor-MVs also exhibit polyphosphates

5 that may activate the contact pathway (B). Pancreatic MVs support robust generation of Xa

6 provided by phosphatidylethanolamine externalization (C). Brain tumors may release

7 Podoplanin (PDPN)-MVs that activate circulating platelets (D). High levels of TF which

8 accumulate in ECs and is recycled to the ECs surfaces $(\mathrm{E})$.

Legend

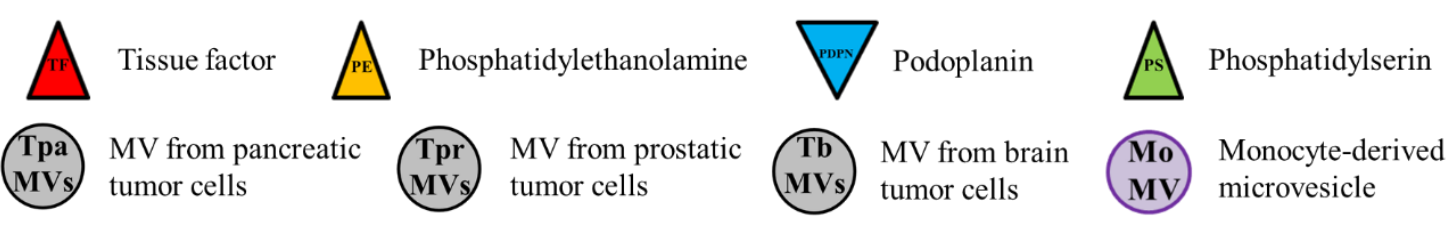

PolyP Polyphosphates

Figure 2: Prothrombotic and antithrombotic molecular pattern of MVs. MVs are initially described to bear procoagulant molecules like phospholipids such as phosphatidylserine (PS) and phosphatidylethanolamine (PE), tissue factor (TF) and polyphosphates. Anticoagulant molecules have been more recently described at the surface of MVs like TFPI, thrombomodulin (TM) that activate proteins $\mathrm{C}$, its cofactor protein $\mathrm{S}$ and the receptor EPCR. The role of MVs in hemostasis was complicated by the presence of proteins of the fibrinolytic system : the tissue-type plasminogen activator (tPA) and urokinase (uPA) and its receptor uPAR and their principal inhibitor (PAI-1). MVs can also carry directly plasminogen on its receptors such as $\alpha$-enolase.

\section{Bibliography}


1. van der Pol E, Böing AN, Harrison P, et al. Classification, functions, and clinical relevance of extracellular vesicles. Pharmacol Rev 2012; 64: 676-705.

2. Boulanger CM, Loyer X, Rautou P-E, et al. Extracellular vesicles in coronary artery disease. Nat Rev Cardiol 2017; 14: 259-72.

3. György B, Szabó TG, Pásztói M, et al. Membrane vesicles, current state-of-the-art: emerging role of extracellular vesicles. Cell Mol Life Sci CMLS 2011; 68: 2667-88.

4. Ciardiello C, Cavallini L, Spinelli C, et al. Focus on Extracellular Vesicles: New Frontiers of Cellto-Cell Communication in Cancer. Int J Mol Sci 2016; 17: 175.

5. Dignat-George $\mathrm{F}$, Boulanger $\mathrm{CM}$. The many faces of endothelial microparticles. Arterioscler Thromb Vasc Biol 2011; 31: 27-33.

6. Ridger VC, Boulanger CM, Angelillo-Scherrer A, et al. Microvesicles in vascular homeostasis and diseases. Thromb Haemost 2017; 117: 1296-316.

7. Engelmann B, Massberg S. Thrombosis as an intravascular effector of innate immunity. Nat Rev Immunol 2013; 13: 34-45.

8. Suzuki J, Umeda M, Sims PJ, et al. Calcium-dependent phospholipid scrambling by TMEM16F. Nature 2010; 468: 834-8.

9. Lhermusier T, Chap H, Payrastre B. Platelet membrane phospholipid asymmetry: from the characterization of a scramblase activity to the identification of an essential protein mutated in Scott syndrome. J Thromb Haemost JTH 2011; 9: 1883-91.

10. Dvorak HF, Quay SC, Orenstein NS, et al. Tumor shedding and coagulation. Science 1981; 212: 923-4.

11. Dvorak HF, Van DeWater L, Bitzer AM, et al. Procoagulant activity associated with plasma membrane vesicles shed by cultured tumor cells. Cancer Res 1983; 43: 4434-42.

12. Collier MEW, Ettelaie C. Regulation of the incorporation of tissue factor into microparticles by serine phosphorylation of the cytoplasmic domain of tissue factor. J Biol Chem 2011; 286: 11977-84.

13. Collier MEW, Maraveyas A, Ettelaie C. Filamin-A is required for the incorporation of tissue factor into cell-derived microvesicles. Thromb Haemost 2014; 111: 647-55.

14. Rothmeier AS, Marchese P, Petrich BG, et al. Caspase-1-mediated pathway promotes generation of thromboinflammatory microparticles. J Clin Invest 2015; 125: 1471-84.

15. Ettelaie C, Collier MEW, Featherby S, et al. Oligoubiquitination of tissue factor on Lys 255 promotes Ser253-dephosphorylation and terminates TF release. Biochim Biophys Acta 2016; 1863: 2846-57.

16. Rothmeier AS, Marchese P, Langer F, et al. Tissue Factor Prothrombotic Activity Is Regulated by Integrin-arf6 Trafficking. Arterioscler Thromb Vasc Biol 2017; 37: 1323-31.

17. Sabatier F, Roux V, Anfosso F, et al. Interaction of endothelial microparticles with monocytic cells in vitro induces tissue factor-dependent procoagulant activity. Blood 2002; 99: 3962-70. 
18. Meziani F, Delabranche X, Asfar P, et al. Bench-to-bedside review: circulating microparticles--a new player in sepsis? Crit Care Lond Engl 2010; 14: 236.

19. Del Conde I, Shrimpton CN, Thiagarajan P, et al. Tissue-factor-bearing microvesicles arise from lipid rafts and fuse with activated platelets to initiate coagulation. Blood 2005; 106: 1604-11.

20. Collier MEW, Mah P-M, Xiao Y, et al. Microparticle-associated tissue factor is recycled by endothelial cells resulting in enhanced surface tissue factor activity. Thromb Haemost 2013; 110: $966-76$.

21. Cointe S, Lacroix R, Dignat-George F. Platelet-Derived Microparticles. Platelets Thromb NonThromb Disord 2017.

22. Mazurov A, Antonova O, Golubeva, N. Procoagulant Properties of Microparticles Produced by Monocytes, Granulocytes, Platelets and Endothelial Cells. Res Pr Thromb Haemost Berlin; 2017; 1:443-444.

23. Tripisciano C, Weiss R, Eichhorn T, et al. Different Potential of Extracellular Vesicles to Support Thrombin Generation: Contributions of Phosphatidylserine, Tissue Factor, and Cellular Origin. Sci Rep 2017; 7: 6522.

24. Van Der Meijden PEJ, Van Schilfgaarde M, Van Oerle R, et al. Platelet- and erythrocyte-derived microparticles trigger thrombin generation via factor XIla. J Thromb Haemost JTH 2012; 10: 1355-62.

25. Rubin O, Delobel J, Prudent M, et al. Red blood cell-derived microparticles isolated from blood units initiate and propagate thrombin generation. Transfusion (Paris) 2013; 53: 1744-54.

26. Angelillo-Scherrer A. Leukocyte-derived microparticles in vascular homeostasis. Circ Res 2012; 110: 356-69.

27. Halim ATA, Ariffin NAFM, Azlan M. Review: the Multiple Roles of Monocytic Microparticles. Inflammation 2016; 39: 1277-84.

28. Stojkovic S, Thulin $\AA$, Hell L, et al. IL-33 stimulates the release of procoagulant microvesicles from human monocytes and differentially increases tissue factor in human monocyte subsets. Thromb Haemost 2017; 117: 1379-90.

29. Kambas K, Chrysanthopoulou A, Vassilopoulos D, et al. Tissue factor expression in neutrophil extracellular traps and neutrophil derived microparticles in antineutrophil cytoplasmic antibody associated vasculitis may promote thromboinflammation and the thrombophilic state associated with the disease. Ann Rheum Dis 2014; 73: 1854-63.

30. Egorina EM, Sovershaev MA, Olsen JO, et al. Granulocytes do not express but acquire monocyte-derived tissue factor in whole blood: evidence for a direct transfer. Blood 2008; 111: 1208-16.

31. Geddings JE, Mackman N. Tumor-derived tissue factor-positive microparticles and venous thrombosis in cancer patients. Blood 2013; 122: 1873-80.

32. Ettelaie C, Collier ME, Featherby S, et al. Analysis of the potential of cancer cell lines to release tissue factor-containing microvesicles: correlation with tissue factor and PAR2 expression. Thromb J 2016; 14: 2. 
33. Gomes FG, Sandim V, Almeida VH, et al. Breast-cancer extracellular vesicles induce platelet activation and aggregation by tissue factor-independent and -dependent mechanisms. Thromb Res 2017; 159: 24-32.

34. Falati $\mathrm{S}$, Liu $\mathrm{Q}$, Gross $\mathrm{P}$, et al. Accumulation of tissue factor into developing thrombi in vivo is dependent upon microparticle P-selectin glycoprotein ligand 1 and platelet P-selectin. J Exp Med 2003; 197: 1585-98.

35. Chou J, Mackman N, Merrill-Skoloff G, et al. Hematopoietic cell-derived microparticle tissue factor contributes to fibrin formation during thrombus propagation. Blood 2004; 104: 3190-7.

36. Owens AP, Mackman N. Microparticles in hemostasis and thrombosis. Circ Res 2011; 108: 1284-97.

37. Zwicker Jl, Trenor CC, Furie BC, et al. Tissue factor-bearing microparticles and thrombus formation. Arterioscler Thromb Vasc Biol 2011; 31: 728-33.

38. Reitsma PH, Versteeg HH, Middeldorp S. Mechanistic view of risk factors for venous thromboembolism. Arterioscler Thromb Vasc Biol 2012; 32: 563-8.

39. Mege $D$, Crescence L, Ouaissi $M$, et al. Fibrin-bearing microparticles: marker of thromboembolic events in pancreatic and colorectal cancers. Oncotarget 2017; 8: 97394-406.

40. Hisada Y, Mackman N. Mouse models of cancer-associated thrombosis. Thromb Res 2018; 164 Suppl 1: S48-53.

41. Sørensen HT, Mellemkjaer L, Olsen $\mathrm{JH}$, et al. Prognosis of cancers associated with venous thromboembolism. N Engl J Med 2000; 343: 1846-50.

42. Tesselaar MET, Romijn FPHTM, Van Der Linden IK, et al. Microparticle-associated tissue factor activity: a link between cancer and thrombosis? J Thromb Haemost 2007; 5: 520-7.

43. Zwicker Jl, Liebman HA, Neuberg D, et al. Tumor-derived tissue factor-bearing microparticles are associated with venous thromboembolic events in malignancy. Clin Cancer Res Off J Am Assoc Cancer Res 2009; 15: 6830-40.

44. Manly DA, Wang J, Glover SL, et al. Increased microparticle tissue factor activity in cancer patients with Venous Thromboembolism. Thromb Res 2010; 125: 511-2.

45. Campello E, Spiezia L, Radu CM, et al. Endothelial, platelet, and tissue factor-bearing microparticles in cancer patients with and without venous thromboembolism. Thromb Res 2011; 127: 473-7.

46. Khorana AA, Francis CW, Menzies KE, et al. Plasma tissue factor may be predictive of venous thromboembolism in pancreatic cancer. J Thromb Haemost 2008; 6: 1983-5.

47. van Doormaal F, Kleinjan A, Berckmans RJ, et al. Coagulation activation and microparticleassociated coagulant activity in cancer patients. An exploratory prospective study. Thromb Haemost 2012; 108: 160-5.

48. Sartori MT, Della Puppa A, Ballin A, et al. Circulating microparticles of glial origin and tissue factor bearing in high-grade glioma: a potential prothrombotic role. Thromb Haemost 2013; 110: 378-85. 
49. Bharthuar A, Khorana AA, Hutson A, et al. Circulating microparticle tissue factor, thromboembolism and survival in pancreaticobiliary cancers. Thromb Res 2013; 132: 180-4.

50. Woei-A-Jin FJSH, Tesselaar MET, Garcia Rodriguez P, et al. Tissue factor-bearing microparticles and CA19.9: two players in pancreatic cancer-associated thrombosis? $\mathrm{Br} J$ Cancer 2016; 115: 332-8.

51. van Es $N$, Hisada $\mathrm{Y}$, Di Nisio $\mathrm{M}$, et al. Extracellular vesicles exposing tissue factor for the prediction of venous thromboembolism in patients with cancer: A prospective cohort study. Thromb Res 2018; 166: 54-9.

52. Faille $\mathrm{D}$, Bourrienne $\mathrm{M}-\mathrm{C}$, de Raucourt $\mathrm{E}$, et al. Biomarkers for the risk of thrombosis in pancreatic adenocarcinoma are related to cancer process. Oncotarget 2018; 9: 26453-65.

53. Thaler J, Ay C, Weinstabl $\mathrm{H}$, et al. Circulating procoagulant microparticles in cancer patients. Ann Hematol 2011; 90: 447-53.

54. Thaler J, Ay C, Mackman N, et al. Microparticle-associated tissue factor activity, venous thromboembolism and mortality in pancreatic, gastric, colorectal and brain cancer patients. J Thromb Haemost 2012; 10: 1363-70.

55. Hernández $\mathrm{C}$, Orbe J, Roncal $\mathrm{C}$, et al. Tissue factor expressed by microparticles is associated with mortality but not with thrombosis in cancer patients. Thromb Haemost 2013; 110: 598608.

56. Cui C-J, Wang G-J, Yang S, et al. Tissue Factor-bearing MPs and the risk of venous thrombosis in cancer patients: A meta-analysis. Sci Rep 2018; 8: 1675.

57. Hisada $\mathrm{Y}$, Mackman N. Cancer-associated pathways and biomarkers of venous thrombosis. Blood 2017; 130: 1499-506.

58. Mege D, Mezouar S, Dignat-George F, et al. Microparticles and cancer thrombosis in animal models. Thromb Res 2016; 140: 21-6.

59. Thomas GM, Panicot-Dubois L, Lacroix R, et al. Cancer cell-derived microparticles bearing Pselectin glycoprotein ligand 1 accelerate thrombus formation in vivo. J Exp Med 2009; 206: 1913-27.

60. Mezouar S, Darbousset R, Dignat-George F, et al. Inhibition of platelet activation prevents the $P$-selectin and integrin-dependent accumulation of cancer cell microparticles and reduces tumor growth and metastasis in vivo. Int J Cancer 2015; 136: 462-75.

61. Thomas GM, Brill A, Mezouar S, et al. Tissue factor expressed by circulating cancer cell-derived microparticles drastically increases the incidence of deep vein thrombosis in mice. J Thromb Haemost 2015; 13: 1310-9.

62. Geddings JE, Hisada $\mathrm{Y}$, Boulaftali $\mathrm{Y}$, et al. Tissue factor-positive tumor microvesicles activate platelets and enhance thrombosis in mice. J Thromb Haemost 2016; 14: 153-66.

63. Hisada Y, Ay C, Auriemma AC, et al. Human pancreatic tumors grown in mice release tissue factor-positive microvesicles that increase venous clot size. J Thromb Haemost 2017; 15: 2208-17. 
64. Date K, Ettelaie C, Maraveyas A. Tissue factor-bearing microparticles and inflammation: a potential mechanism for the development of venous thromboembolism in cancer. J Thromb Haemost JTH 2017; 15: 2289-99.

65. Stark K, Schubert I, Joshi U, et al. Distinct Pathogenesis of Pancreatic Cancer MicrovesicleAssociated Venous Thrombosis Identifies New Antithrombotic Targets In Vivo. Arterioscler Thromb Vasc Biol 2018; 38: 772-86.

66. Lee AYY, Levine MN, Baker RI, et al. Low-molecular-weight heparin versus a coumarin for the prevention of recurrent venous thromboembolism in patients with cancer. N Engl J Med 2003; 349: 146-53.

67. Lee AYY, Kamphuisen PW, Meyer G, et al. Tinzaparin vs Warfarin for Treatment of Acute Venous Thromboembolism in Patients With Active Cancer: A Randomized Clinical Trial. JAMA 2015; 314: 677-86.

68. Streiff MB, Milentijevic D, McCrae K, et al. Effectiveness and safety of anticoagulants for the treatment of venous thromboembolism in patients with cancer. Am J Hematol 2018; 93: 66471.

69. Nickel KF, Ronquist G, Langer F, et al. The polyphosphate-factor XII pathway drives coagulation in prostate cancer-associated thrombosis. Blood 2015; 126: 1379-89.

70. Nickel KF, Labberton L, Long AT, et al. The polyphosphate/factor XII pathway in cancerassociated thrombosis: novel perspectives for safe anticoagulation in patients with malignancies. Thromb Res 2016; 141 Suppl 2: S4-7.

71. Suzuki-Inoue $\mathrm{K}$, Kato $\mathrm{Y}$, Inoue $\mathrm{O}$, et al. Involvement of the snake toxin receptor CLEC-2, in podoplanin-mediated platelet activation, by cancer cells. J Biol Chem 2007; 282: 25993-6001.

72. Thaler J, Koder S, Kornek G, et al. Microparticle-associated tissue factor activity in patients with metastatic pancreatic cancer and its effect on fibrin clot formation. Transl Res J Lab Clin Med 2014; 163: 145-50.

73. Riedl J, Preusser M, Nazari PMS, et al. Podoplanin expression in primary brain tumors induces platelet aggregation and increases risk of venous thromboembolism. Blood 2017; 129: 18319.

74. Leal AC, Mizurini DM, Gomes T, et al. Tumor-Derived Exosomes Induce the Formation of Neutrophil Extracellular Traps: Implications For The Establishment of Cancer-Associated Thrombosis. Sci Rep 2017; 7: 6438.

75. Tans G, Rosing J, Thomassen MC, et al. Comparison of anticoagulant and procoagulant activities of stimulated platelets and platelet-derived microparticles. Blood 1991; 77: 2641-8.

76. Dahlbäck B, Wiedmer T, Sims PJ. Binding of anticoagulant vitamin K-dependent protein S to platelet-derived microparticles. Biochemistry 1992; 31: 12769-77.

77. Stavenuiter F, Davis NF, Duan E, et al. Platelet protein S directly inhibits procoagulant activity on platelets and microparticles. Thromb Haemost 2013; 109: 229-37.

78. Pérez-Casal M, Downey C, Fukudome $\mathrm{K}$, et al. Activated protein $\mathrm{C}$ induces the release of microparticle-associated endothelial protein $C$ receptor. Blood 2005; 105: 1515-22. 
79. Satta N, Freyssinet JM, Toti F. The significance of human monocyte thrombomodulin during membrane vesiculation and after stimulation by lipopolysaccharide. $\mathrm{Br} J$ Haematol 1997; 96: 534-42.

80. Steppich B, Mattisek C, Sobczyk D, et al. Tissue factor pathway inhibitor on circulating microparticles in acute myocardial infarction. Thromb Haemost 2005; 93: 35-9.

81. Tsimerman G, Roguin A, Bachar A, et al. Involvement of microparticles in diabetic vascular complications. Thromb Haemost 2011; 106: 310-21.

82. Aharon A, Tamari T, Brenner B. Monocyte-derived microparticles and exosomes induce procoagulant and apoptotic effects on endothelial cells. Thromb Haemost 2008; 100: 878-85.

83. Aharon A, Katzenell S, Tamari T, et al. Microparticles bearing tissue factor and tissue factor pathway inhibitor in gestational vascular complications. J Thromb Haemost 2009; 7: 1047-50.

84. Aharon A, Sabbah A, Ben-Shaul S, et al. Chemotherapy administration to breast cancer patients affects extracellular vesicles thrombogenicity and function. Oncotarget 2017; 8: 63265-80.

85. Gheldof D, Mullier F, Chatelain B, et al. Inhibition of tissue factor pathway inhibitor increases the sensitivity of thrombin generation assay to procoagulant microvesicles. Blood Coagul Fibrinolysis Int J Haemost Thromb 2013; 24: 567-72.

86. Hellum M, Franco-Lie I, $\varnothing v$ steb $\varnothing \mathrm{R}$, et al. The effect of corn trypsin inhibitor, anti-tissue factor pathway inhibitor antibodies and phospholipids on microvesicle-associated thrombin generation in patients with pancreatic cancer and healthy controls. PloS One 2017; 12: e0184579.

87. Dolo V, Ginestra A, Ghersi G, et al. Human breast carcinoma cells cultured in the presence of serum shed membrane vesicles rich in gelatinolytic activities. J Submicrosc Cytol Pathol 1994; 26: $173-80$.

88. Ginestra A, Monea S, Seghezzi G, et al. Urokinase plasminogen activator and gelatinases are associated with membrane vesicles shed by human HT1080 fibrosarcoma cells. J Biol Chem 1997; 272: 17216-22.

89. Dolo V, Ginestra A, Cassarà D, et al. Selective localization of matrix metalloproteinase 9, beta1 integrins, and human lymphocyte antigen class I molecules on membrane vesicles shed by 8701-BC breast carcinoma cells. Cancer Res 1998; 58: 4468-74.

90. Dolo V, D'Ascenzo S, Violini S, et al. Matrix-degrading proteinases are shed in membrane vesicles by ovarian cancer cells in vivo and in vitro. Clin Exp Metastasis 1999; 17: 131-40.

91. Ginestra A, Miceli D, Dolo V, et al. Membrane vesicles in ovarian cancer fluids: a new potential marker. Anticancer Res 1999; 19: 3439-45.

92. Graves LE, Ariztia EV, Navari JR, et al. Proinvasive properties of ovarian cancer ascites-derived membrane vesicles. Cancer Res 2004; 64: 7045-9.

93. Millimaggi D, Festuccia C, Angelucci A, et al. Osteoblast-conditioned media stimulate membrane vesicle shedding in prostate cancer cells. Int J Oncol 2006; 28: 909-14. 
94. Ginestra A, La Placa MD, Saladino F, et al. The amount and proteolytic content of vesicles shed by human cancer cell lines correlates with their in vitro invasiveness. Anticancer Res 1998; 18: 3433-7.

95. Angelucci A, D'Ascenzo S, Festuccia C, et al. Vesicle-associated urokinase plasminogen activator promotes invasion in prostate cancer cell lines. Clin Exp Metastasis 2000; 18: 16370.

96. Jung $T$, Castellana D, Klingbeil $P$, et al. CD44v6 dependence of premetastatic niche preparation by exosomes. Neoplasia N Y N 2009; 11: 1093-105.

97. McCready J, Sims JD, Chan D, et al. Secretion of extracellular hsp90alpha via exosomes increases cancer cell motility: a role for plasminogen activation. BMC Cancer 2010; 10: 294.

98. Lacroix R, Sabatier F, Mialhe A, et al. Activation of plasminogen into plasmin at the surface of endothelial microparticles: a mechanism that modulates angiogenic properties of endothelial progenitor cells in vitro. Blood 2007; 110: 2432-9.

99. Dejouvencel T, Doeuvre L, Lacroix R, et al. Fibrinolytic cross-talk: a new mechanism for plasmin formation. Blood 2010; 115: 2048-56.

100. Lacroix R, Plawinski L, Robert $S$, et al. Leukocyte- and endothelial-derived microparticles: a circulating source for fibrinolysis. Haematologica 2012; 97: 1864-72.

101. Lacroix R, Dignat-George F. Microparticles: new protagonists in pericellular and intravascular proteolysis. Semin Thromb Hemost 2013; 39: 33-9.

102. Kwaan HC, Rego EM. Role of microparticles in the hemostatic dysfunction in acute promyelocytic leukemia. Semin Thromb Hemost 2010; 36: 917-24.

103. Durrieu L, Bharadwaj A, Waisman DM. Analysis of the thrombotic and fibrinolytic activities of tumor cell-derived extracellular vesicles. Blood Adv 2018; 2: 1054-65.

104. Al-Nedawi K, Szemraj J, Cierniewski CS. Mast cell-derived exosomes activate endothelial cells to secrete plasminogen activator inhibitor type 1. Arterioscler Thromb Vasc Biol 2005; 25: 1744-9.

105. Al Saleh HA, Haas-Neill S, Al-Hashimi A, et al. Thrombotic characteristics of extracellular vesicles derived from prostate cancer cells. The Prostate 2018; 78: 953-61.

106. Lacroix R, Dubois $C$, Leroyer AS, et al. Revisited role of microparticles in arterial and venous thrombosis. J Thromb Haemost JTH 2013; 11 Suppl 1: 24-35.

107. Vallier L, Cointe S, Lacroix R, et al. Microparticles and Fibrinolysis. Semin Thromb Hemost 2017; 43: 129-34.

108. Cointe S, Harti Souab K, Bouriche T, et al. A new assay to evaluate microvesicle plasmin generation capacity: validation in disease with fibrinolysis imbalance. J Extracell Vesicles 2018; 7: 1494482.

109. Lacroix $R$, Judicone $C$, Poncelet $P$, et al. Impact of pre-analytical parameters on the measurement of circulating microparticles: towards standardization of protocol. J Thromb Haemost JTH 2012; 10: 437-46. 
110. Coumans FAW, Brisson AR, Buzas El, et al. Methodological Guidelines to Study Extracellular Vesicles. Circ Res 2017; 120: 1632-48.

111. Shpacovitch V, Hergenröder R. Optical and surface plasmonic approaches to characterize extracellular vesicles. A review. Anal Chim Acta 2018; 1005: 1-15.

112. Laroche $\mathrm{M}$, Dunois $\mathrm{C}$, Vissac $\mathrm{AM}$, et al. Update on functional and genetic laboratory assays for the detection of platelet microvesicles. Platelets 2017; 28: 235-41.

113. Poncelet $\mathrm{P}$, Robert $\mathrm{S}$, Bailly $\mathrm{N}$, et al. Tips and tricks for flow cytometry-based analysis and counting of microparticles. Transfus Apher Sci Off J World Apher Assoc Off J Eur Soc Haemapheresis 2015; 53: 110-26.

114. Nolan JP, Jones JC. Detection of platelet vesicles by flow cytometry. Platelets 2017; 28: 25662.

115. Hisada $\mathrm{Y}$, Auriemma AC, Alexander W, et al. Detection of tissue factor-positive extracellular vesicles by laser scanning confocal microscopy. Thromb Res 2017; 150: 65-72.

116. Exner T, Joseph J, Low J, et al. A new activated factor X-based clotting method with improved specificity for procoagulant phospholipid. Blood Coagul Fibrinolysis Int J Haemost Thromb 2003; 14: 773-9.

117. Jy W, Horstman LL, Jimenez JJ, et al. Measuring circulating cell-derived microparticles. J Thromb Haemost JTH 2004; 2: 1842-51.

118. Hemker HC, Giesen P, AlDieri R, et al. The calibrated automated thrombogram (CAT): a universal routine test for hyper- and hypocoagulability. Pathophysiol Haemost Thromb 2002; 32: 249-53.

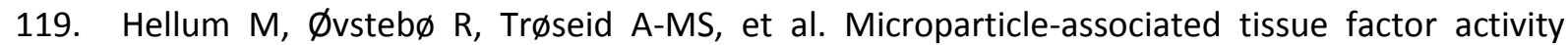
measured with the Zymuphen MP-TF kit and the calibrated automated thrombogram assay. Blood Coagul Fibrinolysis Int J Haemost Thromb 2012; 23: 520-6.

120. Hisada $\mathrm{Y}$, Alexander $\mathrm{W}$, Kasthuri R, et al. Measurement of microparticle tissue factor activity in clinical samples: A summary of two tissue factor-dependent FXa generation assays. Thromb Res 2016; 139: 90-7.

121. Tatsumi K, Antoniak S, Monroe DM, et al. Evaluation of a new commercial assay to measure microparticle tissue factor activity in plasma: communication from the SSC of the ISTH. J Thromb Haemost 2014; 12: 1932-4.

122. Vallier L, Bouriche T, Bonifay A. New specific and highly sensitive procoagulant test to measure tissue factor activity on microparticles. Res Pr Thromb Haemost Berlin; 2017; 1:1087.

123. Hisada $\mathrm{Y}$, Mackman N. Measurement of tissue factor activity in extracellular vesicles from human plasma samples. Res Pr Thromb Haemost [Internet] 2018 [cited 2018 Dec 8]; 0: . Available from: https://onlinelibrary.wiley.com/doi/abs/10.1002/rth2.12165

124. Biró E, Sturk-Maquelin KN, Vogel GMT, et al. Human cell-derived microparticles promote thrombus formation in vivo in a tissue factor-dependent manner. J Thromb Haemost 2003; 1: 2561-8. 
1 125. Berckmans RJ, Sturk A, van Tienen LM, et al. Cell-derived vesicles exposing coagulant tissue 2 factor in saliva. Blood 2011; 117: 3172-80.

3

4

5

6 